\title{
Health Protection in Ghana and Senegal: What is the ILO's Role?
}

\author{
Juliette Alenda-Demoutiez, Abena Asomaning Antwi, Elvire Mendo and \\ Zrampieu Sarah Ba
}

\begin{abstract}
In West Africa, the right of access to universal social security is far from being respected. International institutions and African governments have been mobilising for several years to fight this phenomenon. In a role that has evolved over the years, the International Labour Organization (ILO) provides technical and financial support to countries in this regard. How and why does the ILo intervene in protecting the health of populations in West Africa? For this institutional study, the methodology is based on a literature review focused on the history of the role of the ILO in the protection of healthcare in West Africa, specifically in Ghana and Senegal. We show the ILO's involvement since the 1990s for two main reasons: firstly, the lack of access to healthcare in countries with a specific labour form; secondly, the rejection of the idea of social protection by dominant players on the international scene, leading to criticism following the structural adjustment programmes. In the contexts of Ghana and Senegal, both of which have experienced transitions from community-based health mechanisms to universal health coverage, we explain that the ILo has several ways to intervene-technically, institutionally, and financially. An important outcome is the revelation that the vision of the ILO with regard to health protection is systemic, articulating alternative ways to address social protection for the informal economy compared to other international organisations. But this approach is understated considering the dire situation in Africa and the need to improve access to healthcare and progress towards the Sustainable Development Goals.
\end{abstract}

\section{Introduction}

Inequalities persist among and within countries in sub-Saharan Africa. In 2013, 41 per cent of the continent's population lived on less than USD 1.90 per day (World Bank, 2016). And the right of access to universal social security is not

(C) JULIETTE ALENDA-DEMOUTIEZ ET AL. 2019 | DOI:10.1163/9789004399013_007

This is an open access chapter distributed under the terms of the prevailing CC-BY-NC license at the time offipublication. 
being upheld. International institutions and African governments have mobilised for several years to address this. The objective of this movement has been to ensure substantial coverage of the poor and most vulnerable by 2030 in these countries and to put in place sustained social protection measures.

However, sub-Saharan countries have different paths in the establishment of what the World Health Organization (wHO) calls Universal Health Coverage (UHC), ${ }^{1}$ due to political, economic and social reasons. The International Labour Organization (ILO) provides technical, financial, and institutional support to these countries in their efforts to achieve this goal. Although it is not the only international actor involved in protecting the health of African populations, it has interesting characteristics-its actions have been carried out for several years in both the formal and informal sectors, in a role that has evolved since its inception and that was not devolved to the organisation originally. Thus, how and why does the ILO intervene in protecting the health of populations in West Africa?

Firstly, through a parallel history between the ILO, its vision of social protection, and the evolution of health insurance systems in West Africa, we seek to understand why the ILO has played this important role of protecting the health of inhabitants in this region, but also the laws put in place in these countries since 2000. Secondly, we contextualise two West African countries, Ghana and Senegal, in analysing particular interventions and the place of the ILO in supporting community-based movements towards national health insurance schemes, in line with its Social Protection Floor (SPF) Recommendation. Finally, we discuss two points that are important and that emerge from this analysis: the opportunity for the ILO in maintaining its important role in the development of recommendations, with a systemic framework regarding health and labour in developing countries; the institutional and technical obstacles in a complex and saturated sector with diverse actors.

The methodology for this institutional analysis is composed of several stages. A first review of the literature allows us to better understand the links between the ILO, its evolution and the health coverage systems in West Africa. The link between the ILO and the countries under study, particularly through mutual health organisations (M HOs), has already been observed by some participant researchers in previous works. The second step is a systematic review of the two countries concerned. We predetermined first a set of parameters regarding

1 UHC in developing countries is, according to the wHO definition in the 2010 World Health Report, to 'provide all people with access to needed health services of sufficient quality to be effective', and to 'ensure that the use of these services does not expose the user to financial hardship' (WHO, 2010, 6). 
health, work, and the ILO. The literature mobilised comes from academic and institutional sources. An analysis of common and differential trends is made, adopting an approach that consists of comparing homogeneities and peculiarities in understanding the ILO's role in each context.

\section{The ILO's Vision, from Its Origin to Its Interventions in West Africa}

\subsection{Before the 199os, a Vision Based on Wage Labour}

The ILO's vision of social protection and labour has remained but the scope of its missions and activities has evolved over the last hundred years. Before 1944, the focus was more on a technical vision of health than on socio-economic conditions (Weindling, 1995). In the thirties, it began to develop technical cooperation activities, first with Latin America. These technical cooperation activities grew with international development programmes after 1945 (Guthrie, 2013). The aims and purposes of the ILO became larger after the International Labour Conference of 1944, taking in welfare, including several missions on the protection of health. Social security, including medical coverage and care for all, became one of its goals.

This vision of social protection was strongly Western-based, relying on the principle of wage labour; this continued until the 1990s. For the ILO, social protection was to be organised on a large scale by the state and/or public institutions, with the assumption that members of society have already reached a certain standard of living and that this should be protected (Jütting, 2002). With the decolonisation of African countries in the 196os, the ILO persisted with this vision, with the idea that a growing part of the populations of developing countries would eventually join the formal wage sector of the economy and thus benefit from the social protection of health, for themselves and their families (ILO, 2001).

This vision has been applied in West African countries, first by their colonisers, and then during independence. While Western health insurance systems have a long history, the oldest formal health coverage systems in West Africa are the result of the colonial era. Systems were created by the colonising countries to protect expatriates. During this time, some were extended to urban and industrial African workers in order to maintain their productivity. These systems are at the root of what exists for formal sector workers and civil servants in most West African countries. These are traditional, European-style health coverage systems, based on the Beveridge model (national coverage), tax-financed and state-run, or Bismarck model (social security), financed by contributions from workers and employers and managed by an independent 
fund. After decolonisation, West African countries decided for the most part to provide free public healthcare in public institutions. The state financed and provided these services. At the same time, social security systems persisted, sometimes expanding, diffusing the legitimacy of such systems in relation to their effectiveness in Western countries. Countries that did not experience widespread coverage under colonisation nevertheless took inspiration from Western systems, still seeking the legitimacy of these methods (Destremeau and Lautier, 2006). But the focus was on occupational diseases and accidents at work.

The end of the 1980 s marked a sudden change in the way health protection was managed, from free to direct payment, in a context of economic crisis. Indebted African countries were looking for help in the form of international cooperation. In return, states withdrew from healthcare provision and imposed programmes influenced by the neo-liberal doctrine (Plassart, 2011). Structural adjustment programmes (SAPs) targeted spending that was considered excessive, health being part of this (Berkhout and Oostingh, 2008). By then, international financial institutions did not have a monopoly of these initiatives. But, from 1980, the United Nations went through a crisis, with its role turning away from economic aid and towards humanitarian aid. Three institutions-the International Monetary Fund, World Bank and World Trade Organizationgradually became the pillars of the global economy and of development strategies (Favreau, 2003). The logic changed: the goal was no longer development but economic growth. This era was marked by deteriorations in infrastructure, a shortage of medicines, deteriorations in working conditions and a flight of qualified personnel due to the health sector being underfunded.

\subsection{A New Vision of Social Security for Development}

In the 1990s, the vision of the ILO evolved in terms of the form that social security could take in Africa and the organisation began intensive lobbying to bring social protection back to the forefront of development. An international consensus had been formed incrementally, denouncing the injustice of the direct payment system and the SAPs. Health coverage became the new objective, the goal being to make it possible to extend access to healthcare through a fairer and more viable financing mechanism in the long term, provided that health care services improved (Alenda-Demoutiez, 2016).

But the problem remains the same for the ILO. Promoting social protection cannot be done in the same way in Africa as in Western countries. This brought about two important changes in the ILO's vision: the extension of social security through decentralised, community-based mechanisms, and a better consideration of the informal economy. The ILO is still promoting the ratification and 
implementation of Convention No. $102(1952)^{2}$ concerning social security. But to take account of different national contexts, flexibility clauses are included.

\subsubsection{Community-based Mutual Health Organisations}

Interpersonal solidarity in West Africa has been important in terms of compensating for the lack of protection in terms of healthcare. Family ties, community support or help from the informal economy to employees all contribute to health. Faced with significant needs and a population unable to access care, MHOs, and more particularly community-based MHOs, emerged in the 1980s, impelled primarily by socio-professional, sociocultural, faith-based, and women's groups.

An мно is 'a voluntary, non-profit insurance scheme, formed on the basis of an ethic of mutual aid, solidarity and the collective pooling of health risks, in which the members participate effectively in its management and functioning' (Atim, 1998, 2). Nowadays, many forms of M HOs exist, divided into two groups: complementary or 'top-up' M HOs, designed by and for formal sector workers, and MHOs providing 'first-dollar' cover (i.e. 100 per cent insurance with no excess). The latter aim at households that do not have existing health cover and are therefore the priority target group for extension policies. These 'first-dollar' MHOS consist primarily of community-based MHOs based in a neighbourhood, village or district. Their origins are diverse: they may have been set up by residents of a neighbourhood, members of a community, voluntary associations, health providers, etc.

This particular mechanism gained momentum in the 1990s, with ILO support. Those excluded from social security, and its extension, were the organisation's new key focus for development, and this priority was affirmed at the 89th session of the International Labour Conference in 2001. For the ILO, the development of community-based health systems is the result of a real demand for socio-professional or community organisations. Hence its support for these organisations from that moment. While $76 \mathrm{MHO}$ were registered in West Africa in 1997, 366 were created in 2003 and 626 in 2006, according to estimates (Ridde, 2012).

2 The Social Security (Minimum Standards) Convention is based on basic social security principles; it establishes worldwide-agreed minimum standards for all nine branches of social security (medical care, sickness, unemployment, old age, employment injury, family, maternity, invalidity, and survivors' benefits). While Convention No. 102 covers all the branches, it requires that only three of these branches be ratified by Member states, which allows for the step-by-step extension of social security coverage by ratifying countries. 


\subsubsection{The Informal Economy}

The concept of the informal sector, as used for the first time by Keith Hart (1973), refers to the economy unknown to public policymakers. As it evolved, it became characterised by pejorative elements, such as small size, a non-capitalist way of producing, etc. (Laville, 2010). This sector is regarded as the failure of development. However, the ILO shows the influence of its social-democratic vision in its definition of the informal sector, or the informal economy.

The ILO at first considered the informal economy as 'units engaged in the production of goods or services with the primary objective of generating employment and incomes to the persons concerned'. The definition continues: 'These units typically operate at a low level of organization, with little or no division between labour and capital as factors of production and a small scale. Labour relations - where they exist - are based mostly on casual employment, kinship or personal and social relations rather than contractual arrangements with formal guarantees' (ILO, 1993, 52). Thus, the ILO focuses on different elements than other international organisations: the emphasis on labour before capital, solidarity, social responsibility. The measurement of the informal economy was a problem, forcing the ILO to restrain its definition in order to operationalise it - 'a group of production units which [...] form part of the household sector as household enterprises or, equivalently, unincorporated enterprises owned by households' (ILO, 1993, 53). This definition was limited to enterprises. In 2003, the 17 th International Conference of Labour Statisticians at the ILO tried a new perspective, focused directly on jobs and people, and not on structures: 'The purpose of the conceptual framework developed for the ILO report was to relate the enterprise-based concept of employment in the informal sector in a consistent manner with a job-based concept of informal employment, and thereby extend the former concept to a broader one' (ILO, 2003, 49). From this point, informal and formal economies are viewed as complementary.

The ILO's vision thus presents a systemic approach to health protection in Africa, prioritising the excluded: it is a question of adapting to the shape of the labour market, mostly informal, but also to the needs of people. Actions of the ILO in Africa focus on these two areas.

\subsection{From Decentralised Mechanisms to Social Protection Floors}

Beginning in the 1990s, the ILO focused on microenterprises, cooperatives and especially, in this case, on social health protection through MHOs. The ILO, like the United States Agency for International Development (USAID), the German Organisation for Technical Cooperation (GIZ), the National Alliance of Christian Mutuals (ANMC, Belgium), and Solidarité Mondiale (a Belgian non-governmental 
organisation), has played a vital role in developing MHOs in West Africa since the 1990s. The ILO was formerly involved through its ACOPAM/ILO programme (Cooperative and Organisational Support to Grassroots Initiatives), as early as 1978. ${ }^{3}$ This programme lasted until 1999. The other international stakeholders have been mainly involved since 1998, the date of the platform of Abidjan. ${ }^{4}$ For the ILO, social protection has two main objectives: to guarantee income security (following illness, maternity, work accident, unemployment, disability, old age, or death of a member of the family) and to guarantee access to care of an acceptable quality and at a reasonable cost. The notions of democracy, empowerment, social cohesion and decentralisation are also important, which makes it easy for the ILO to accept the principle of community-based MHOS.

In 2004, Clive Bailey, for the ILO's Global Campaign on Social Security and Coverage for All, wrote: 'The reality in Africa however, is that there is also a need for different and innovative approaches, of which micro insurance schemes based on solidarity and redistribution within the group is but one example. There is often a need for a blend of activities, which strike a balance between community-based initiatives, the strengthening of public social security schemes, and the development of universal schemes for health care and other benefits' (Bailey, 2005, 2). A new consensus on social security was adopted at the 2001 International Labour Convention, leading to the launch of the Global Campaign on Social Security and Coverage for All in 2003. This was followed in 2008 by the Declaration on Social Justice for a Fair Globalization, by the Global Jobs Pact in 2009, and by the SPF Recommendation in 2012.

The SPF is a flagship initiative of the ILO. It is defined as 'an integrated set of social policies designed to guarantee income security and access to social services for all, paying particular attention to vulnerable groups, and protecting and empowering people across the life cycle' (ILO, 2011, xxii). The strategy comprises two dimensions. The first, expansion of social security by a basic set of social guarantees, is the horizontal dimension. The second dimension consists of implementing progressively higher standards from minimum standards, representing the vertical dimension. Also, the SPF integrates healthcare for all, social protection for all children, support for all people of working age in the event of unemployment, maternity, disability or work-related accidents, and retirement pensions for all the elderly. Based on local needs and capabilities, countries can adapt the recommendation.

3 It was a multi-bi ILo programme financed by Norway, originally to respond to the severe drought in the Sahel region at that time and ended in 1999.

4 The platform of Abidjan is the result of the collective reflection of the different actors involved in the promotion of MHOs gathered at a workshop held in Abidjan in June 1998. 
Thus, the ILO has been involved in protecting health in Africa for two main reasons. The first is pragmatic: in the 199os, people in West Africa did not have access to care or social protection, particularly those working in the informal economy. The second is institutional: international recommendations with regard to development have exacerbated Africa's problems, and the dominant players on the international scene rejected the idea of social protection in developing countries, leaving room for criticism of the obvious failures of previous programmes in the developing world.

The Role of the ILO in Health Protection in Ghana and Senegal

\subsection{Ghana and Senegal: Two 'Exemplary' Countries Regarding Health Protection in Africa}

Ghana, Senegal and Rwanda are often presented as examples in sub-Saharan Africa regarding progress in health indicators and the expansion of mutual health insurance. We restrict our comparison to Ghana and Senegal, two countries in West Africa - the focus of our study - that offer interesting common trends in their economic, social and institutional make-up (Table 6.1). The Republic of Ghana, in West Africa, is located on the shores of the Gulf of Guinea and is surrounded by Côte d'Ivoire, Burkina Faso and Togo. It was one of the first countries in the continent to achieve independence, in March 1957. The political history of the country has been turbulent, particularly in the 1980s, but has stabilised. The official language is English. The Republic of Senegal, also in West Africa, is surrounded by Mauritania, Mali, Guinea, and Guinea-Bissau and is open to the Atlantic Ocean. In April 1960, the country became independent. Senegal is also politically stable. Of all the languages spoken there, French remains the official language.

Regarding health, the disease burden of the continent includes HIV/AIDS, maternal and infant mortality, non-communicable diseases, and other conditions. The recorded HIV/AIDS prevalence rate is very low in Senegal and there is a lower infant mortality rate than in other West African countries, but there are wide disparities at regional levels and within urban and rural populations. In Ghana, in comparison to indicators on health in the subregion, the incidence of non-communicable diseases is higher (Saleh, 2012). With regards to health coverage, both countries have chalked up some successes, with reductions observed in under- 5 child mortality and maternal mortality rates. A significant proportion of the population works in the informal sector. In Senegal, agriculture and fisheries employ around 44 per cent of the population and this is no different from Ghana, where the population is predominantly rural. Child labour is an important feature of informal work in both countries. 


\begin{tabular}{lcc}
\hline & Ghana & Senegal \\
\hline Population & 28 million & 15 million \\
Population under 15 & 42 per cent & 42 per cent \\
Life expectancy & 61 (women) $/ 57$ (men) & 69 (women) $/ 65$ (men) \\
Unemployment rate & 16.6 per cent $(2016)$ & $15 \cdot 7$ per cent $(2015)$ \\
Share of population in & 80 per cent & 88 per cent \\
informal sector & & 14.79 billion \\
GDP (UsD) & 139th & 170 th \\
HDI (rank) & Lower middle-income & Lower middle-income \\
Income status & 21.8 per cent & 37 per cent \\
Child labour rates $\left(5^{-17}\right.$ & & \\
years)
\end{tabular}

SOURCE: THE AUTHORS, BASED ON WORLD BANK DATA AND THE GHANA LIVING STANDARDS SURVEYS; BAUMANN (2010); MOSS AND MAJEROWICZ (2012); BITRAN (2014).

The governments of Ghana and Senegal have made political commitments to implement UHC by involving M HOs. Both countries seek to apply the ILO's dual strategy on which the SPF programme is based: a horizontal dimension, having primary health protection for the whole population, and a vertical dimension, improving existing protection from risk. Another common point in both countries is that the first community-based мно os appeared in 1989, supported by a Catholic diocese: the Nkoranza Community Health Insurance Scheme at St. Theresa Hospital in Sunyani District for Ghana; the Fandène M Ho, supported by the Saint Jean-de-Dieu Hospital, in the Thiès region for Senegal. In the ensuing sections of this chapter, the specific case of each country is examined in order to illustrate the various interventions carried out by the ILO and the specificities of this path to UHC.

\subsection{Senegal and the ILO/STEP Programme}

Until 2012, only around 20 per cent of the Senegalese population had (limited) health coverage. Among those covered were civil servants (7.35 per cent of the population), covered by the system inherited from the colonial era, and wage earners in the formal sector (3.6o per cent), protected by the Instituts de Prévoyance Maladie, social security funds created in 1975. The elderly—covered 
when above 60 ( 4.87 per cent of the population)—and members of MHOs (3.79 per cent) were also covered (CAFSP, 2008). Since the Fandène MHO in 1989, MHOs have developed rapidly, first in that same region of Thiès as well as in Dakar and then throughout the country. Despite the absence of complete censuses, from 19 functional units (units that are in activity) in 1997, they increased to 129 in 2007 and to 200 in 2008 in Senegal (Villane and Faye, 2008).

The government-level transition in the health system settled in the first decade of the new millennium, with the promotion of MHOs. In 1996, CAMICS (Cellule d'appui aux mutuelles de santé, aux IPM et comités de santé) was created to support the creation and the evolution of MHOs in the country. Attached to the Prevention Department, the organisation brought together several stakeholders with the intention of strengthening the capacities of the promoters of мноs and to create links with health structures. By 2003, the country developed a legal framework for MHOs.

The ILO's Strategies and Tools against Social Exclusion and Poverty (STEP) programme's role in this process was influential. The STEP programme (under the Social Security Department) was the operational instrument of the Global Campaign on Social Security and Coverage for All. It operated on two levels: forming direct support to the promoters of mutuals; pursuing advocacy for the extension of social protection. In Senegal, and more generally in West Africa, the ILO, through this programme, fought to see the creation of legal frameworks to supervise MHOs. The ILO was one of the CAMICS' partners that supported the 'Concertation' - an organisation bringing together several African countries and international structures - the objective of which was to create an exchange network between MHOs. In 2004, in Senegal, the UHC Agency relied on several promoters, particularly on the ILO, in its mission to improve social protection and promote MHOs. From 2003 to 2006, the ILO also supported the establishment of a legal framework on MHOs in the eight members of the Economic Community of West African States. The ILO and USAID as well as other donors (French, Belgian and German) have all been involved in Senegalese mHOs (Alenda-Demoutiez, 2016). The ILO/STEP programme has supported the creation and capacity-building of various community-based MHOs, such as the Werwerlé MHOs in Dakar and Thiès or the PAMECAS мно in Pikine. In the first decade of the new millennium, the ILO/STEP programme supported MHOs through training and funding programmes, including the creation of the Dakar M HOs Union.

In 2012, the newly elected president, Macky Sall, announced the introduction of UHC. The objectives were ambitious. The proposition was for 75 per cent coverage of the population by 2017. On the one hand, the compulsory and medical assistance schemes were strengthened for civil servants and the 
formal sector; on the other, voluntary M HOs developed in order to cover the rest of the population. As part of the experimentation of the National Strategy for the Extension of Health Risk Coverage, a decentralised scheme was developed, calling for at least one мно per local authority and setting up unions by department. The total coverage was 32 per cent in 2014, according to the UHC Agency. Since 2013, M HOs have received government grants, calculated in relation to their membership fee. In this way, community мноs are supposed to take charge of primary care (through contributions), while the state takes responsibility for secondary care. USAID and Abt Associates ${ }^{5}$ are the government's main partners in its efforts to move towards UHC.

\subsection{Ghana's Path towards the National Health Insurance Scheme (NHIS)}

Ghana, since its independence in 1957, has experienced various evolutions in its health system. As in Senegal, the country chose free healthcare before implementing the SAPs in the 1980s. In the 1990s, the 'Cash and Carry' system was established, introducing full payment for medication. Although the first M HO was created in 1989, their development was especially important in the late 1990s. In 2001, the country had 47 MHOs, 43 of which were created in 1999 or 2000 (Atim et al., 2001), and 168 in 2003 (Diop et al., 2006). MHOs, as in Senegal, originated from various sources (healthcare providers, ethnic networks, social movements mainly for employees in the formal urban sector, etc.) (Atim, 1998). But unlike in Senegal where m HOs are dominant, Ghana has seen the evolution of both MHOs and of other community-based mechanisms, experimenting with various types of microinsurance. In 2003, Ghana had less than 1 per cent of its population covered by health insurance (Diop et al., 2006).

The ILO intervened institutionally from 2001 to 2003, through a global trust fund. This fund provided strategic guidance on the feasibility of communitybased M HOs and the promulgation of the new law regarding mutual health insurance. But, unlike in Senegal, the STEP programme has not been involved in Ghana's MHOS. The environment with regard to international institutions was different, with the presence of the Danish International Development Agency (DANIDA) and USAID's Partners for Health Reformplus (PHRplus) programme. On the domestic front, the Catholic Church played an important role in the development of мноs, at the regional and district health assemblies level. Earlier in the 1990s, WHO, the ILO, the European Union, the Ghana Medical Association and labour unions had called on the government to create health

5 Abt Associates is a global research and programme implementation firm based in the US, providing expertise on health, social and environmental policy, climate change, and international development. 
insurance to offset the negative consequences of the 'Cash and Carry' system (Fusheini et al., 2012).

In contrast to the system existing in Senegal for civil servants and employees in the formal sector, Ghana decided to rely on an extension of the social security system based on the principle of mutual health insurance for the entire population. Thanks to institutional arrangements between the decentralised administration system and national policies, the extension of coverage, from 2003 to 2005, was trialled in all districts in the country paving the way for the NHIS. To establish the National Health Insurance Act, a consultation process was initiated between the two main partners, DANIDA and USAID, and also the ILO, WHO, the UK Department for International Development and relevant non-governmental organisations (Mensah et al., 2010).

The NHIS and Community-Based Health Planning and Services (CHPS) in Ghana are based on the principles of equity, solidarity, the pooling of risks, cross-subsidisation, partnership, the democratic participation of all stakeholders, sustainability, and geographical and financial reach for all. Act No. 650 initially established three kinds of health insurance schemes in the country: District Mutual Health Insurance (DMHI) schemes, Private Mutual Health Insurance schemes, and Private Commercial Health Insurance. The National Health Insurance Council was set up, giving technical support to DMHIs. These DMHIs are allowed to operate as companies limited by guarantee and are thus autonomous. In 2012, the law was revised (Act 852) and brought the district insurance schemes into a single, pooled fund. The Ministry of Health is the lead ministry for the National Health Insurance Authority, which manages the scheme. Policy is formulated at the national level, where the accreditation of health services, the monitoring and evaluation of MHOs, logistics and technical support also take place. Thus, the extension of health coverage has been achieved through the NHIS (for financial access) and the CHPS (for geographical access), although with initial progress, the enrolment in the NHIs has stagnated at 40 per cent of the population since the scheme's inception and for the CHPS at 5 per cent (Atim and Amporfu, 2016). Unlike Senegal, which separates health protection for civil servants, the formal sector and the informal economy, the system is the same for all in Ghana. All contribute-formal sector employees pay a percentage of their salaries, informal economy workers pay a flat premium, and an important part of NHIS funding comes from value added tax. While Senegal is seeking to combine different forms of health insurance, Ghana has brought everything together into a single system (government, other public initiatives, private sector insurance, community-based health mechanisms) (Wietler, 2010). 
The ILo has been involved directly in health coverage in Ghana through capacity building, undertaking several initiatives aimed at improving the competency levels of people involved in social security. The ILO provided technical and policy advice to the government of Ghana on the administration of the NHIs. The Financial, Actuarial and Statistical Services Branch of the ILO in particular has been closely participating in a technical capacity, advising on national health budgets, the institutional infrastructures required, mediumterm financial planning and implementation (ILO, 2005). Further examples of this effort are the training and capacity building of staff of the Social Security and National Insurance Trust, where the administration of pensions for formal sector workers is domiciled (and which also forms a regular flow of revenue for the NHIS), building capacity in actuarial science and budgeting (some of which has occurred through a collaborative effort between the ILO and the University of Maastricht), and the development of a health budget model for Ghana (Dovlo, 2005).

\section{Discussion: A Systemic Vision}

Two strong points emerge from this analysis regarding the ILo's role in the health of the populations of West Africa. Both represent opportunities for the ILO in its efforts to maintain its important role in developing recommendations, but they are also institutional and technical obstacles. The first is the importance of the informal economy in West African countries and the role of the ILO in its protection, within a systemic framework. The second is the role of the ILO on the international scene regarding development, in a complex and saturated space with various actors.

\subsection{A Systemic Vision between Health and Labour}

In Africa as in the rest of the world, the organisation is, at a national and regulatory level, using what has been its principal tool since its inception: the ratification of conventions. Ghana and Senegal have been members of the ILO since independence, in the process ratifying several important conventions. In West Africa, these conventions and recommendations can be considered as a complementary tool, difficult to apply but fundamental to well-being in the long term. Convention 102 still influences many African health protection systems, countries setting up pension schemes modelled on it, even if formal social security systems cover only a small portion of their populations. This Convention is still regarded as a goal for development (Servais, 2014). In this way, 
the ILO emphasises the importance of governance conventions in improving the application of international labour standards. But collective agreements, complaints (filed by workers when employers do not respect a convention) and the ability to act on these rules are mainly based on the strength of trade unions. It is public unions that mainly take a central role with regard to labour demands in these two countries. The functioning and relations between the different unions in these countries can also be problematic. In Senegal, teachers can affiliate to any of some 30 different unions. Thus, the various actions of the ILO depend on the strength of public institutions, on trade unions and on the access of information for workers about their rights, in models where formal wage labour is not the norm.

The magnitude of the informal sector and its diversity in Africa has, above all, obliged states and international organisations to make an effort to define interventions that take into account the need to promote the actors, and contain the growth, of the informal sector. The attitude of governmental and institutional actors with regard to the informal sector has evolved. The initial desire to curb its expansion has given way to a certain tolerance, even a willingness to support it. In Senegal, the informal economy is considered an important cultural element that enables the majority of the population excluded from the formal sector to subsist and is widely accepted by all. It is not considered an end but a means (Fall, 2011). Thus, while employment is one of the components of Senegalese reforms, ${ }^{6}$ there is no intention-for the moment-to eradicate the informal economy, the approach, rather, being to develop it in order to achieve 'more decent' work (Kanté, 2002).

Overall, there is a broad consensus on the need to improve incomes and productivity in the informal sector so as to reduce poverty and bring the sector's economic and employment conditions closer to those of the formal sector. This justifies the ILO's involvement in the health protection of workers in both sectors in the countries studied, and the development of мноs to reach the informal economy. Finding and delineating a contributory basis is indeed complex with a dominant informal form of labour. The concept of 'decent work,' ${ }^{7}$ appeared for the first time in 1999, in the report presented by the Director General of the ILO to the 87th Session of the International Labour

6 Employment (especially for young people) is a strong part of the national Strategy for social and economic development, within two axes, growth and human capital.

7 According to the official webpage of the ILO (available at http://www.ilo.org/global/topics/ decent-work/lang--en/index.htm, accessed on 11 June 2018), the 'decent work sums up the aspirations of people in their working lives. It involves opportunities for work that is productive and delivers a fair income, security in the workplace and social protection for families, better prospects for personal development and social integration, freedom for people to express 
Conference. The concept is based on four pillars: employment, social protection, workers' rights and social dialogue. The term 'employment' here refers to work in all its forms. As a result, the concept applies not only to workers in the formal economy, but also to informal employees, the self-employed, and home-based workers (Ghai, 2003). The SPF programme is, essentially, part of the 'decent work' vision of the ILO, covering the health of workers and their families.

The ILO thus outlines a very systemic vision of the health of the populations of West African countries. A system, in the systemic approach, is considered to be the organised totality of a set of active and interdependent units that relate to and interact with one another through flows. There are interactions between system elements, both to stabilise the system and to make it evolve. The study of a system must be coupled with the study of its transformations, and the converse is true. Systems are complex and must be approached as a whole-since the whole is more than the sum of the parts-and not in a reductionist way (Donnadieu and Karsky, 2002). In practice, this involveswhen analysing the impact of a policy or actor-always thinking about its consequences and its interactions with the entire system. The systemic approach provides another contribution to efforts to take into account the diversity of factors that influence health (work, environment, education, the cohesion of various health-financing schemes, etc.). The systemic approaches, the 'Health in All Policy' programmes, ${ }^{8}$ the analyses of social inequalities and of the social determinants of health are developing in the developed as in the developing world, but they are far from being generalised.

\subsection{The ILO and the International Environment}

For West African countries, the role of the ILO has been and remains important and systematic. In the 1990 it filled a vacuum, working to improve health protection for informal workers in African countries, in contrast to the position taken by international financial institutions. Thus, we have noted, the actions of the ILO are important for health coverage in West Africa, but also for the organisation itself, by adapting its vision of social protection where formal labour is not the norm. All in all, the ILo's work could be seen as an application of the 'Health in All Policies' approach—an approach whereby, due to the

their concerns, organize and participate in the decisions that affect their lives and equality of opportunity and treatment for all women and men'.

8 'Health in All Policies is an approach to public policies across sectors that systematically takes into account the health implications of decisions, seeks synergies, and avoids harmful health impacts in order to improve population health and health equity' (WHO, 2014, 2). 
ultimate goal of productivity in the workplace, the health and well-being of persons engaged in either the formal or the informal sector is covered. The role of the ILO is also due to the fact that its historical vision of social protection has, for a while, led to it adopting a systemic approach to the safety and health of workers, whereas other international institutions have taken the more restrictive approach of health protection (Alenda-Demoutiez, 2016). While the ILO's action on 'decent work' and social protection in West Africa dates back to the 1990s, it was not until 2010 that WHO promoted the transition to UHC, in 2008 highlighting the need for a systemic approach by all, as reported by the Commission on the Social Determinants of Health (work being, itself, a social determinant of health).

Such broad actions cannot be undertaken without the intervention of other agencies with similar and differing interests. Referring to health protection, the international consensus has turned towards a functionalist view of the state. The challenge is to improve the situation within the constraints of limited resources (Letourmy, 2003). Health insurance is definitely capable of providing a means to alleviate the funding challenges of institutions and to improve the quality of care of populations. Within such a framework, UHC serves as a necessary investment with regard to economic growth and health protection for African countries. But health coverage and social protection have an important redistributive character, emphasising the fact that protection is a factor in social cohesion (Euzéby and Fargeaon, 2011). However, international cooperation targets poverty, not the national cohesion that is fundamental to achieving a sustainable and legitimate system (Stiglitz, 2002). This is one of the special features of the ILO that fits in the national cohesion approach, whereas the World Bank, for example, will focus on economic growth. Social dialogue is core to the ILO's strategy, regarded as the 'social pillar of the United Nations', as opposed to the 'economic pillars' - international financial institutions (Favreau, 2003). For the ILO, promoting social security is a political choice, reflecting a certain vision of society, considering social security as a fundamental human right (Waelkens and Criel, 2004).

Regarding health protection, the ILO and WHO carry out similar tasks, but not exactly the same vision: 'The ILO is a global guardian of human rights and social rights at work; similarly, WHO is a global guardian for the right to both health in general and health at work' (Rantanen et al., 2013, 137). Principally, both the ILO and WHO support social security schemes and UHC. They have jointly taken charge of the SPF initiative since 2009, leading to progress-a joint position paper was developed and a meeting organised for the 19 participating UN agencies, bilateral donor agencies, and international non-governmental organisations. This culminated in the establishment of an 'agreed language' for 
the SPF initiative (Cichon, 2013). As seen from the two examples, the Ghanaian UHC (NHIS and CHPS) and Senegalese UHC are sponsored mainly by USAID and other donors, with support from $\mathrm{WHO}$, thus regaining its recommendatory role with regard to developing countries. For WHO, M HOs are not the solution in themselves: MHOs, and more generally microinsurance, are an interesting tool to develop a financial solidarity between people and become a lever for setting up national systems, public and/or private.

Besides, systemic approaches and solidarity mechanisms as supported by the ILO require a large amount of resources and time, especially considering the dire situation in Africa and the urgent need to improve access to healthcare in developing countries and to progress towards the Sustainable Development Goals. This ties in with the literature on 'government silos', which argues that departments may function as 'silos' within a vertical organisation. These divisions are considered to be barriers to the implementation of effective public policies. According to Carey and Crammond (2015), this 'departmentalism', intended to simplify the process of governance, results in public authorities wanting to restrict themselves to their mandate alone. But this does not promote systemic action by all, which would include an overall evolution of the health system and consideration of the social determinants of health. The WHO has been committed to this vision for several years now, emphasising the importance of systemic and adaptive approaches to specific contexts and social and cultural norms (WHO, 2013). In 2008, the wHO Commission on Social Determinants of Health stated that 'given the marked failure of markets to supply vital goods and services equitably, [the emphasis on public finance] implies strong public sector leadership and adequate public expenditure', advocating for better involvement of the state and local civil society in decisions (CSDH, 2008, 12). But systemic approaches are still too rare, not only in the field of health but also in general (Kelley, 2014; Houéto and Valentini, 2014). And the needs and voice of the population, emphasised by the ILO, are also rarely considered in development programmes generally. International technical efficiency is always emphasised instead of legitimacy of actions and local actors (Alenda-Demoutiez, 2016).

\section{5}

\section{Conclusion}

The ILO is important for the health protection of African workers, especially for those in the informal economy. The action of the ILO in West Africa is very specific and different from its actions the world over. This capacity of adaptation comes in part from the ILO's vision regarding social protection, health, 
and the informal economy. Now, the ILO has a leading role with wHO in the promotion of social security and the protection of the health of formal and informal workers. Its work is divided into many complementary constituents for social protection and poverty reduction. The levels of interventions are broad, varied, and require the capabilities of a systemic approach, adapted to the specific labour and socio-economic structures of developing countries. This resulted in the inclusion of social protection in the Sustainable Development Goals, although the views of development actors are still divergent as to the actual meaning of social protection. The stakes in terms of health and 'decent work' are considerable and matters urgent in West Africa, and the ILO stands in this regard as an inescapable architect for the actualisation of this vision.

\section{References}

Alenda-Demoutiez, J. (2016) Les mutuelles dans l'extension de la couverture maladie au Sénégal. Une lecture par les conventions et l'économie sociale et solidaire, $\mathrm{PhD}$ Dissertation (Villeneuve d'Ascq : University of Lille), http://ori-nuxeo.univ-lillei.fr/nuxeo/ site/esupversions/f72b3c4a-773a-409e-8998-c3698f884cf8 (accessed on 16 February 2018).

Atim, C. (1998) The Contribution of Mutual Health Organizations to Financing, Delivery, and Access to Health Care: Synthesis of Research in Nine West and Central African Countries (Bethesda: Partnerships for Health Reform), http://www.ilo.org/wcmsp5/ groups/public/---ed_protect/---soc_sec/documents/publication/wcms_secsoc_110 .pdf (accessed on 16 February 2018).

Atim, C. and E. Amporfu (2016) Review of the Ghanaian NHIS: What Lessons Have We Learned?, paper presented at the 4 th Conference of the African Health Economics and Policy Association, Rabat, 26-29 September, http://afhea.org/ docs/presetationspdfs/Chris\%20Atim\%20\%2oReview\%20of\%2othe\%2oGhan aian\%20NHIS-\%2oWhat\%2oLessons\%2oHave\%2oWe\%2oLearned_.pdf (accessed on 11 June 2018).

Atim, C., S. Grey, P. Apoya, S.J. Anie and M. Aikins (2001) A survey of health financing schemes in Ghana (Betheseda: Abt Associates, Partners for Health Reform plus), http://www.phrplus.org/Pubs/Techo13_fin.pdf (accessed on 11 June 2018).

Bailey, C. (2005) Extending social security coverage in Africa, ESS Working Paper No. 20 (Geneva: ILO), DOI: https://dx.doi.org/10.2139/ssrn.675624.

Baumann, E. (2010) Protections sociales en Afrique subsaharienne : le cas du Sénégal, NOTE no 56, (Paris: Fondation Jean-Jaurès), http://horizon.documentation.ird.fr/ exl-doc/pleins_textes/divers12-06/010053213.pdf (accessed on 16 February 2018). 
Berkhout, E. and H. Oostingh (2008) Health Insurance in Low Income Countries, Where is the evidence that it works? Oxfam Briefing Paper (Oxford: Oxfam), https://policypractice.oxfam.org.uk/publications/health-insurance-in-low-income-countrieswhere-is-the-evidence-that-it-works-123910 (accessed on 11 June 2018).

Bitran, R. (2014) Universal Health Coverage and the Challenge of Informal Employment: Lessons from Developing Countries, HNP Discussion Paper (Washington, D.C.: The International Bank for Reconstruction and Development / The World Bank), http:// documents.worldbank.org/curated/en/698041468180275003/pdf/87077oREVISED oomaloEmploymentoFINAL.pdf (accessed on 16 February 2018).

CAFSP (Cellule d'Appui au Financement et la Santé et au Partenariat) (2008) Stratégie nationale d'extension de la couverture durisquemaladie des sénégalais (Dakar:USAID, Ministère de la Santé et de la Prévention), http://www.coopami.org/fr/countries/ countries/senegal/social_protection/pdf/strategienationale.pdf (accessed on 16 February 2018).

Carey, G. and B. Crammond (2015) 'Action on the social determinants of health: views from inside the policy process', Social Science and Medicine, 128, pp. 134-141, DOI: 10.1016/j.socscimed.2015.01.024.

Cichon, M. (2013) 'The Social Protection Floors Recommendation, 2012 (No. 202): Can a six-page document change the course of social history?', International Social Security Review, 66(3-4), pp. 21-43, DOI: 10.1111/issr.12017.

CSDH (Commission of the Social Determinants of Health) (2008) Closing the gap in a generation: Health equity through action on the social determinants of health, Commission on Social Determinants of Health Final Report (Geneva: WHO), http:// www.who.int/social_determinants/final_report/csdh_finalreport_2008.pdf (accessed on 16 February 2018).

Destremeau, B. and B. Lautier (2006) Analyse et comparaison des systèmes de protection sociale du monde en développement, Éléments de typologie et de méthode (Paris: Collaboration réseau Impact et CRI).

Diop, F.P., S. Sulzbach and S. Chankova (2006) The Impact of Mutual Health Organizations on Social Inclusion, Access to Health Care, and Household Income Protection: Evidence from Ghana, Senegal, and Mali (Bethesda: The Partners for Health Reformplus Project, Abt Associates Inc.), http://pdf.usaid.gov/pdf_docs/Pnadh424.pdf (accessed on 16 February 2018).

Donnadieu, G. and M. Karsky (2002) La systémique : penser et agir dans la complexité (Paris: Liaisons).

Dovlo, D.Y. (2005) Social dialogue in the health sector: Case study Ghana, Sectoral Activities Programme Working Paper (Geneva: ILO), http://www.ilo.org/wcmsp5/ groups/public/---ed_dialogue/---sector/documents/publication/wcms_161165.pdf (accessed on 16 February 2018). 
Euzéby, C. and V. Fargeaon (2011) 'Droit à la santé et développement humain', in P. Batifoulier, A. Buttard and J-P. Domin (eds.) Santé et politiques sociales : entre efficacité et justice. Autour des travaux de Maryse Gadreau (Paris: Editions Eska), pp. 146-157.

Fall, M.A. (2011) Saint-Louis du Sénégal : et si le développement nétait qu'une chimère? (Paris: L'Harmattan).

Favreau, L. (2003) L'économie sociale et solidaire: contribution éthique au développement d'une mondialisation à visage humain (Gatineau: CRDC, Université du Québec), http://w4.uqo.ca/crdc/oo_fichiers/publications/cahiers/RR7.pdf (accessed on 16 February 2018).

Fusheini, D., G. Marnoch and A.M. Grey (2012) The Implementation of the National Health Insurance Programme in Ghana - an Institutional Approach, paper presented at the 62nd Political Studies Association Annual International Conference in Defence of Politics, Belfast, 3-5 April, http://uir.ulster.ac.uk/22028/1/PSA_2012_Confer ence.pdf (accessed on 16 February 2018).

Ghai, D. (2003) 'Decent work: Concept and indicators', International Labour Review, 142, pp. 113-145, DOI: 10.1111/j.1564-913X.2003.tboo256.x.

Guthrie, J. (2013) 'The ILO and the International Technocratic Class, 1944-1966', in S. Kott and J. Droux (eds.) Globalizing Social Rights, ILO Century Series (London: Palgrave Macmillan), pp. $115^{-134}$.

Hart, K. (1973) 'Informal Income Opportunities and Urban Employment in Ghana', The Journal of Modern African Studies, 11(1), pp. 61-89, http://www.jstor.org/stable/ 159873 (accessed on 11 June 2018).

Houéto, D. and H. Valentini (2014) 'La promotion de la santé en Afrique : histoire et perspectives d'avenir', Santé Publique, HS(S1), pp. 9-20, DOI: 10.3917/spub.140.ooog.

ILO (International Labour Organization) (2011) Social protection floor for a fair and inclusive globalization (Geneva: Social Protection Floor Advisory Group-ILO), http:// www.ilo.org/wcmsp5/groups/public/---dgreports/---dcomm/---publ/documents/ publication/wcms_165750.pdf (accessed on 16 February 2018).

ILO (2005) Improving Social Protection for the Poor: Health Insurance in Ghana (Geneva: The Ghana Social Trust pre-Pilot Project-ILO), http://www.ilo.org/wcmsp5/groups/ public/---ed_protect/---soc_sec/documents/publication/wcms_secsoc_9357.pdf (accessed on 16 February 2018).

ILO (2003) Seventeenth International Conference of Labour Statisticians, Geneva, 24 November-3 December 2003, General Report, http:/www.ilo.org/wcmsp5/groups/ public/---dgreports/---stat/documents/meetingdocument/wcms_087585.pdf (accessed on 16 February 2018).

ILO (2001) Social security: A new consensus (Geneva:ILO), http://www.ilo.org/wcmsp5/ groups/public/---ed_protect/---soc_sec/documents/publication/wcms_209311.pdf (accessed on 16 February 2018). 
ILO (1993) Fifteenth International Conference of Labour Statisticians, Geneva, 19-28 January 1993, Report of the Conference (Geneva: ILO), http://www.ilo.org/public/ libdoc/ilo/1993/93Bo9_65_engl.pdf (accessed on 16 February 2018).

Jütting, J. (2002) Social Risk Management in Rural Areas of Low-Income Countries, An Economic Analysis of Community-Based Health Insurance Schemes (Bonn: Faculty of Agriculture-University of Bonn).

Kanté, S. (2002) Le secteur informel en Afrique subsaharienne francophone : vers la promotion d'un travail décent (Geneva : ILO), http://www.ilo.org/wcmsp5/groups/ public/---ed_emp/documents/publication/wcms_122219.pdf (accessed on 16 February 2018$)$.

Kelley, A. (ed.) (2014) Une vue d'hélicoptère : cartographie des régimes de financement de la santédans 12 pays d'Afrique Francophone, Communauté de Pratique Accès financier aux Services de Santé et Communauté de Pratique Financement Basé sur la Performance, http://www.healthfinancingafrica.org/uploads/8/o/8/8/8088846/rapport _phase_1_recherche_collaborative_muskoka.pdf (accessed on 16 February 2018).

Laville, J.-L. (2010) Politique de l'association (Paris: Seuil).

Letourmy, A. (2003) État et assurance maladie dans les pays africains, paper presented to the 26th Days of French Health Economists, Clermont-Ferrand, 9-10 January, http://cerdi.org/uploads/sfCmsContent/html/194/Letourmy.pdf (accessed on 11 June 2018).

Mensah, J., J.R. Oppong and C.M. Schmidt (2010) 'Ghana's National Health Insurance Scheme in the Context of the Health MDGs-An Empirical Evaluation Using Propensity Score Matching', Health Economics, 19, pp. 95-106, DOI: 10.1002/hec.1633.

Moss, T.J. and S. Majerowicz (2012) No Longer Poor: Ghana's New Income Status and Implications of Graduation from IDA, Center for Global Development Working Paper No. 300 (Washington D.C.: Center for Global Development), DOI: https://dx.doi . org/10.2139/ssrn.2102796.

Plassart, A. (2011) 'La protection sociale : un enjeu mondial ?', in D. Kerouedan (ed.) Santé internationale. Les enjeux de santé au Sud (Paris: Presses de Sciences Po), pp. 247-259.

Rantanen, J., J. Benach, C. Muntaner, T. Kawakami and R. Kim (2013) 'Work, health and employment', in K. Leppo, E. Ollila, S. Peña, M. Wismar and S. Cook (eds.) Health in All Policies, Seizing Opportunities, Implementing Policies (Helsinki: Ministry of Social Affairs and Health), http://www.euro.who.int/_data/assets/pdf_file/o007/188809/ Health-in-All-Policies-final.pdf (accessed on 11 June 2018).

Ridde, V. (2012) L'accès aux soins de santé en Afrique de l'Ouest, au-delà des idéologies et des idées reçues (Montréal: Les presses de l'université de Montréal).

Saleh, K.A. (2012) World Bank Study: A Health Sector in Transition to Universal Coverage in Ghana (Washington D.C.: World Bank), DOI: http://hdl.handle.net/10986/2728. 
Servais, J.-M. (2014) International Standards on Social Security, Lessons from the past for a better implementation, paper presented at the Asian Conference on Globalization and Labour Administration, Manila, 19-21 November, http://islssl.org/wp-content/ uploads/2014/12/Servais_2014_Asian_Conf.pdf (accessed on 16 February 2018).

Stiglitz, J.E. (2002) La grande désillusion (Fayard: Paris).

Villane, C. and M. Faye (2008) 'Les mutuelles de santé, un outil d'extension de la couverture du risaue maladie au Sénégal', in Forum Kurukan Fugan (ed.) Guide des initiatives santé (Dakar: Forum Kurukan Fugan), pp. 5-9.

Waelkens, M. and B. Criel (2004) Les mutuelles de santé en Afrique subsaharienne. Etat des lieux et réflexions sur un agenda de recherche (Washington D.C.: The International Bank for Reconstruction and Development-The World Bank), http:// siteresources.worldbank.org/HEALTHNUTRITIONANDPOPULATION/Resources/ 281627-1095698140167/Waelkens-LesMutuelles-whole.pdf (accessed on 11 June 2018).

Weindling, P. (1995) International Health Organisations and Movements, 1918-1939 (Cambridge: Cambridge University Press).

WHO (World Health Organization) (2014) Health In All Policies: Helsinki Statement. Framework for Country Action (Geneva: WHO), http://apps.who.int/iris/bitstream/ handle/10665/112636/9789241506908_eng.pdf?sequence=1 (accessed on 11 June 2018).

WHO (2013) World Health Report 2013: Research for universal health coverage (Geneva: WHO), http://www.who.int/whr/2013/report/en/ (accessed on 16 February 2018).

WHO (2010) World Health Report: Health systems financing: the path to universal coverage (Geneva:WHO), http://www.who.int/whr/2010/en/ (accessed on 11 June 2018).

Wietler, K. (2010) Mutual Health Organizations in Sub-Saharan Africa-Opportunities and Challenges (Eschborn: GIZ), https://www.giz.de/expertise/downloads/gtz2010en-mutual-health-organisations.pdf (accessed on 16 February 2018).

World Bank (2016) Poverty and Shared Prosperity 2016: Taking on Inequality (Washington, DC: World Bank), DOI: 10.1596/978-1-4648-0958-3. 